\title{
Web-based Application Forecasting of Components and Tools for Practicum in Telecommunication Engineering Laboratory/Workshop of State Polytechnic of Sriwijaya
}

\author{
Elmerillia $^{1 *)}$, Lindawati $^{2)}$, and Irma Salamah ${ }^{3)}$ \\ 1,2,3) Telecommunication Engineering Study Program , Department of Electrical Engineering, \\ State Polytechnic of Sriwijaya, Indonesia \\ Corresponding Email: *) elmerillia.99@gmail.com
}

\begin{abstract}
State Polytechnic of Sriwijaya is an Indonesian vocational institution that incorporates practical learning into all of its existing study programs. In each laboratory of the study program, students will find the supporting components and resources they need for practicum. Telecommunication engineering is one of them. Currently, the component retrieval and tool borrowing system is still manual, both in the retrieval and return stages, by filling out the given hard-file form sheet. Therefore, a web-based inventory monitoring application is required for laboratory technicians. The creation of this application implements the Prototype Method. The implementation of this method aims to make the application that is created to fit the needs of the user. This system helps laboratory technicians and Telecommunication Engineering students in the process of component retrieval and tool borrowing to be more organized and scheduled and can store reports in the form of soft-files. This information system can also be used by students to monitor the number of components and tools available in real-time. This application are also equipped with forecasting the number of practicum components to kwowing the needs of student practicum in the next year. Forecasting was created using the Weighted Moving Average method. Black box testing is carried out in each menu on the application and gives valid results so that the application can be used.
\end{abstract}

Keywords: Web, Prototype Method, Weighted Moving Average, Laboratory

\section{INTRODUCTION}

In Indonesia, technology and information will continue to develop at a rapid pace. These advances have an influence on many aspects of life, including health, economy, society, and, of course, education. [1]. Based on previous research [2], a computer laboratory management application has been created that helps in data processing so that it can produce easier and more accurate information. Other research [3] also utilizes usabilitybased web applications to assist in providing and collecting information and data.

Technology and information development are also projected to continue, with a focus on the State
Polytechnic of Sriwijaya. State Polytechnic of Sriwijaya is a vocational university that incorporates practical learning into all existing study programs. State Polytechnic of Sriwijaya offers students with the necessary supporting components and instruments in each laboratory of the study program. Some of the required components become facilities that students may use without needing to purchase them. Similarly, current learning resources are transformed into an inventory of laboratories that students may access through a loan system.

Currently, the system of component retrieval and tool borrowing is still done manually. Students still have to bring a manual and fill in the data on the loan form provided. The accountability report sheet is collected in each semester of lectures and causes the stacking of hardfile data. Therefore, a web-based application was created with the aim of being able to help technicians and students in the laboratory of the Telecommunication Engineering Study Program in the process of taking components and borrowing tools/instruments in the laboratory to be more organized and scheduled. This system is expected to be a strategy to optimize the target of the study program, which is to have $90 \%$ of the main laboratories and adequate support. The resulting web-based application has the advantage of adding a report data storage system in PDF form. Looking at previous research [4]-[5], the system prioritizes effectiveness and speed of easy-to-reach access. This research applied prototype method which was a method to automate the definition and analysis phase so that it was more specific [6]. Suggestions from users are needed in system development for produce applications to fit the needs.

Each semester of lectures also requires preparation of the number of components that will meet the needs of students in next year according to the needs of each job practicum. Then it takes forecasting to be able to estimate the number of needs of components practicum in the future [7]. Forecasting will involve retrieving historical data and projected for future purposes by applying mathematical models [8]. The mathematical calculation referred to in the discussion here was the use of the Weighted Moving Average method. In this application, 
forecasting menu is made using history data of the needs of component and number of students.

\section{MethodolOGY}

\section{A. Research Framework}

The research framework described the stages to facilitate the implementation of research in order to achieve the desired results. This research framework is created in the form of diagram blocks that state sequential relationships and have their own work unity (see Figure $1)$ :

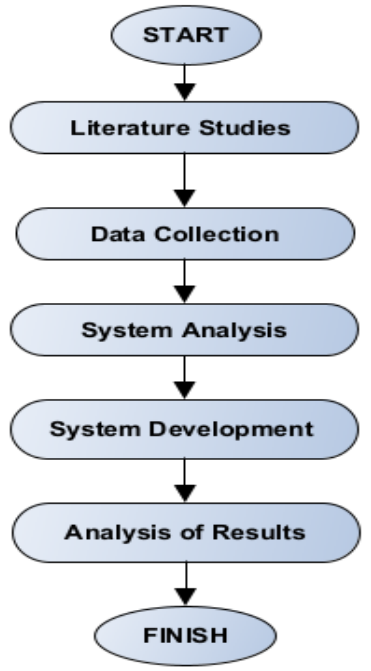

Figure 1. Research Framework

\section{Literature Studies}

At this stage, a search for theory reviews obtained from various journals, books and internet sources was conducted to complete the vocabulary of concepts and theories of the title objects studied [5].

\section{Data Collection}

At this stage, the data collection process was carried out by two methods, namely interviews and field studies (observations) with students, lecturers, laboratory technicians and administrative officers of the Bachelor of Applied Telecommunications Engineering Program [4]. The data that will be displayed in the application is the detail data of the courses in accordance with the existing learning modules.

\section{System Analysis}

At this stage, identification of problems in the current system was carried out. The problems found are found in the system of component retrieval and borrowing of tools/instruments that were still applied to conventional systems.

\section{System Development}

Used the prototype method in application manufacture and the weighted moving average method as a forecasting development method. The software needs used were XAMPP, Visual Studio Code, CodeIgniter, Startboostrap, FPDF, and a web browser. Programming languages used were PHP, CSS, and MySQL [9]-[11].

\section{Analysis of Results}

Analysis of the results was done by conducting tests first using the Black Box Testing method.

\section{B. Application Development Methods}

The Software Development Method (Application) used was the prototype method. The stages of the prototype method are as follows:

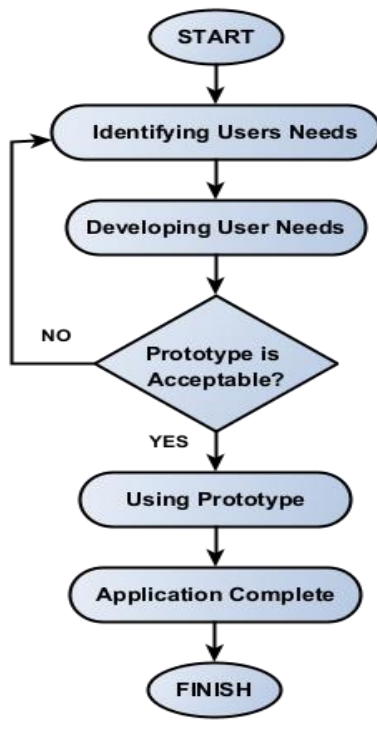

Figure 2. Prototype Method

At the stage of identifying users needs, it conducted interviews with the Laboratory Telecommunication Engineering at State Polytechnic of Sriwijaya, namely Technicians and Students. This stage was done to better know about the obstacles in the laboratory, then got an idea to create the system needed [12]-[13]. Furthermore, building prototypes by creating temporary designs that focus on presentation was to create inputs and outputs according to the needs of the user. Then determine whether the prototype was acceptable or not. This evaluation stage was done to find out if the system was in accordance with the desired for the determination of the next step was coding the system, otherwise there would be revisions to the system that had been built [6]. The last stage of using prototypes to be used as a system until the system was ready for use in the form of applications. Testing of the system was also carried out using black box testing. Blackbox Testing is a method to check the output value based on each input value in a software [14].

\section{Forecasting Development Methods}

The forecasting stage started with inputting data. The required data in the form of component names and the 
required number adjusts to the practicum job in each practicum course and inputs student data. Furthermore, the data would be processed using the weighted moving average method. The formula of the weighted moving average method is as follows:

$$
F_{t}=\frac{C_{1} X_{t-1}+C_{2} X_{t-2}+\ldots+C_{n} X_{t-n}}{C_{1}+C_{2}+\ldots+C_{n}}
$$

It is known that $\mathrm{Ft}$ is the forecast period to $\mathrm{t}, \mathrm{C}$ is the weight used, and $X_{t}$ is the actual data in period $t$, and $n$ is the number of periods for future forecasting [15].

\section{RESULTS AND DiSCUSSION}

\section{A. Identify the User Needs}

The results of user needs identification can be seen in the following diagram use case:

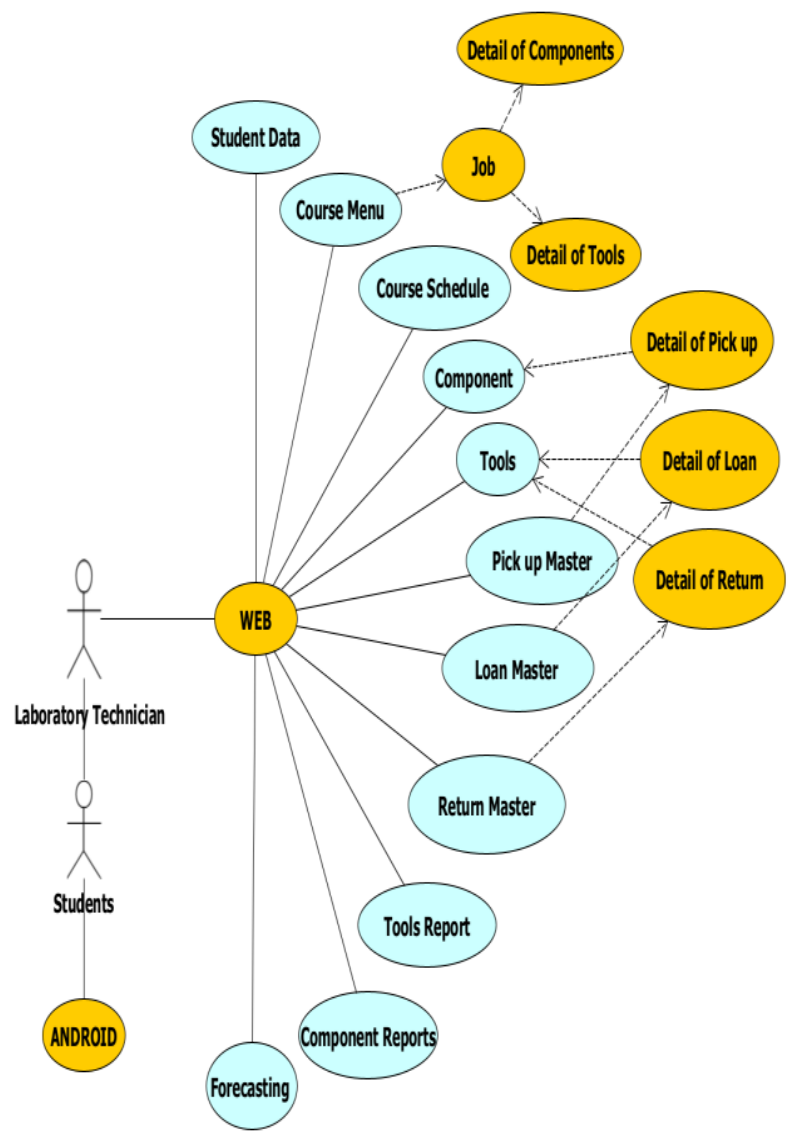

Figure 3. Use Case Diagram

\section{B. Development of the User Needs}

The development of user needs was based on identifying user needs. The following activity diagram draws the results of developing user needs:

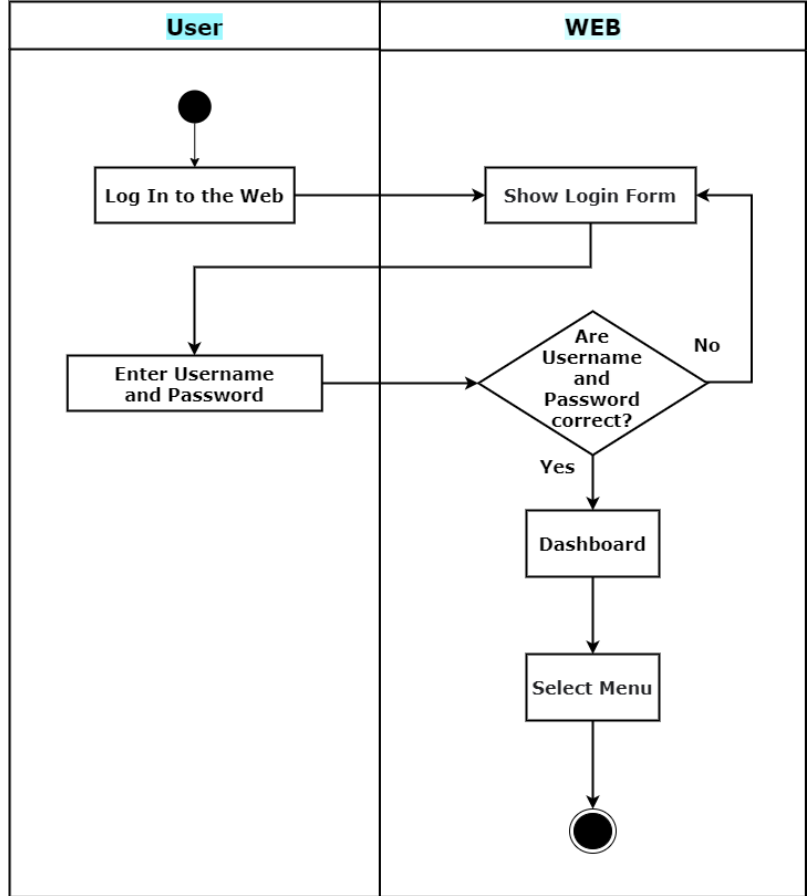

Figure 4. Activity Diagram Log In

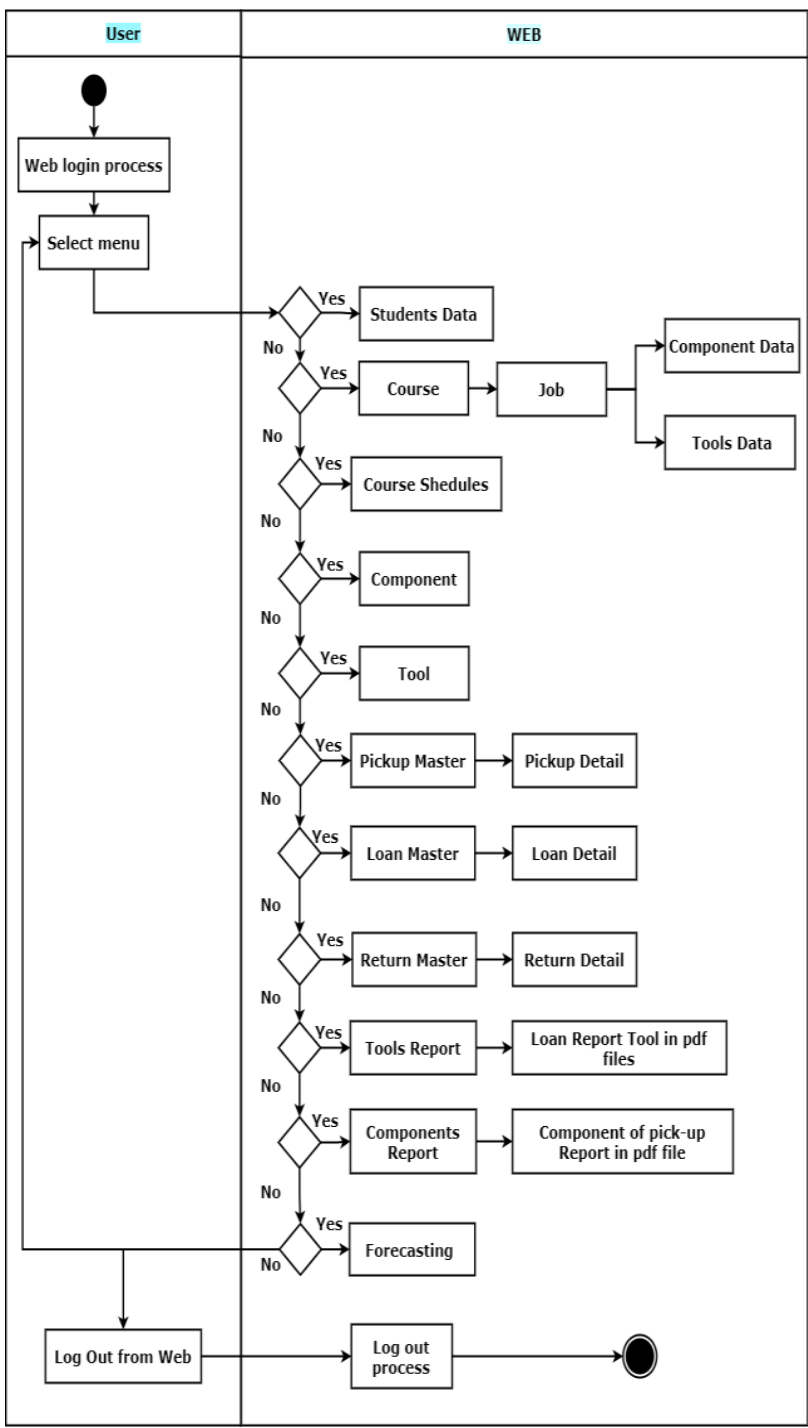

Figure 5. Activity Diagram Menu 


\section{User View Results}

After implementation, the programming language produced Web-based applications. Admins can customize their data by inputting, editing, or deleting data, along with how it looks on the web. Here can be seen the user view image:

\section{Login dan Logout}

In order to access this application, users, namely laboratory/workshops technicians, are required to fill in the username and password on the login form available. In contrast, to maintain data security, the logout menu is also provided.

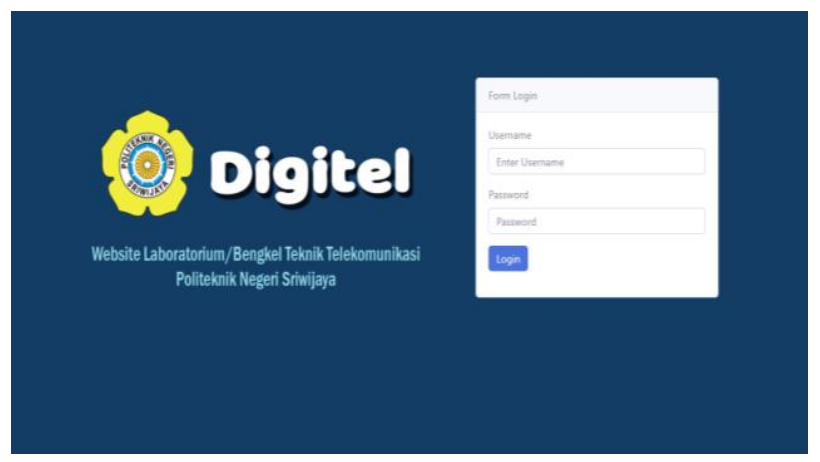

(a)

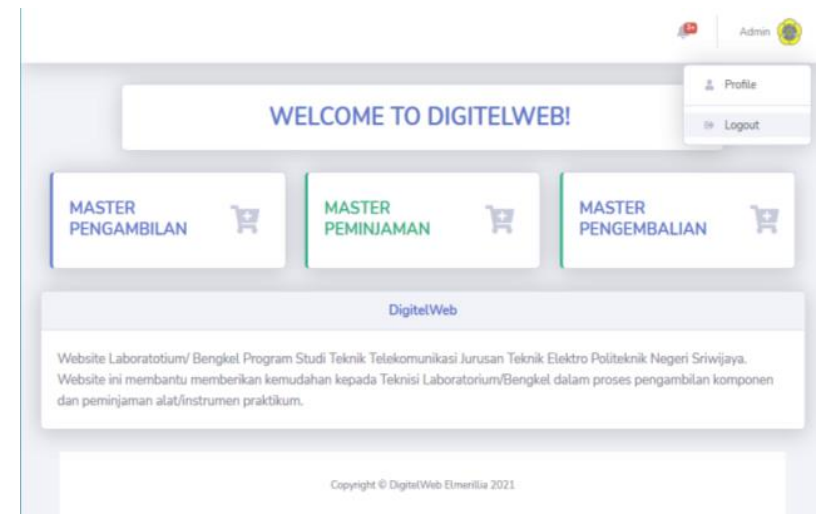

(b)

Gambar 6. (a) Login menu and (b)Logout

\section{Dashboard Menu}

After logging in, the web will immediately display the dashboard.

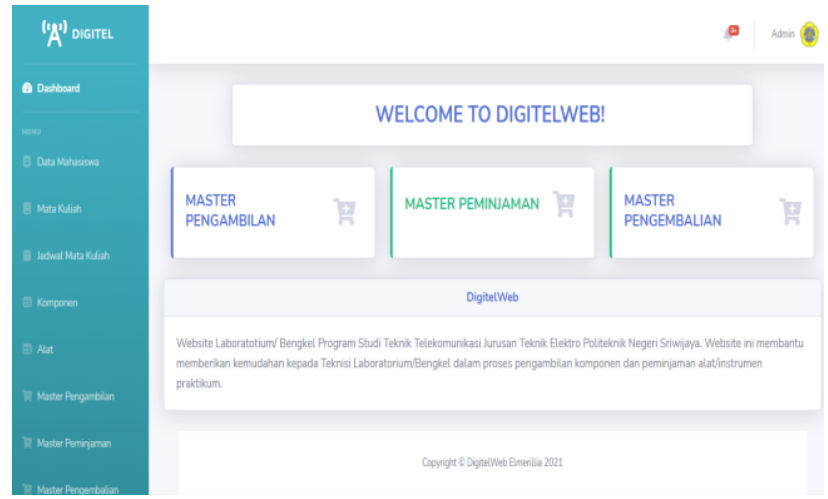

Figure 7. Dashboard Menu

\section{Student Data Menu}

This menu displays data information of active students of Telecommunication Engineering Study Program at State Polytechnic of Sriwijaya.

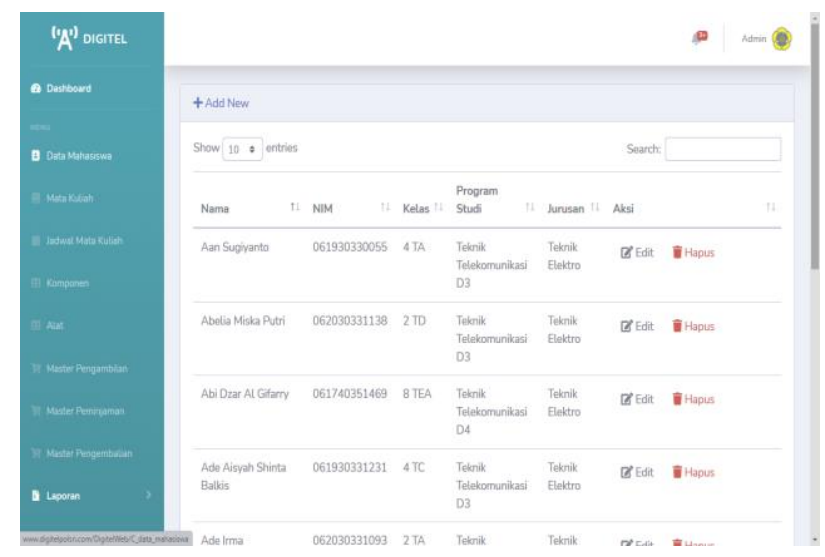

Figure 8. Student Data Menu

\section{Course Menu}

In the course menu there are 3 information that can be accessed, namely course data, practical course job data, and detailed data of components and tools of each practicum job.

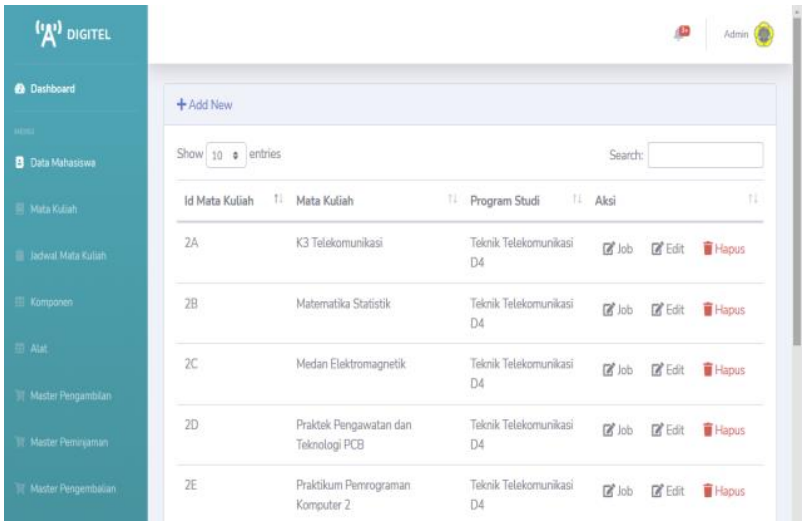

(a)

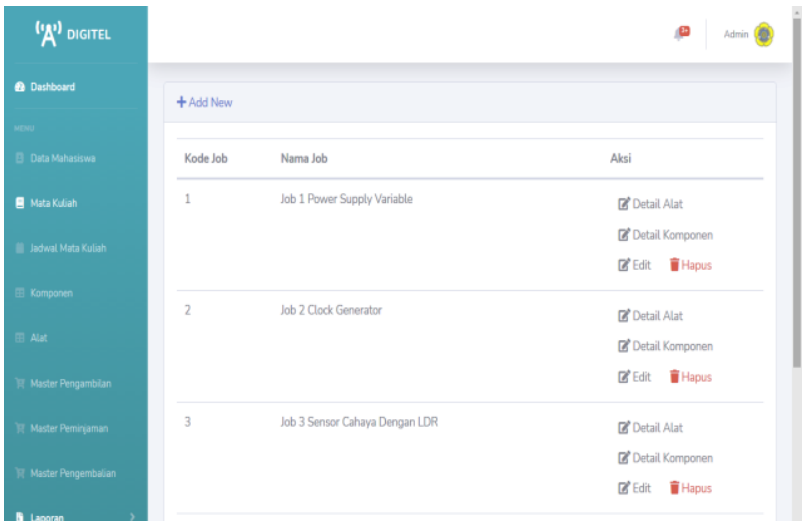

(b)

Figure 9. (a) Course Menu and (b)Job Menu

\section{Course Schedule Menu}

This menu provides information on course schedules. 


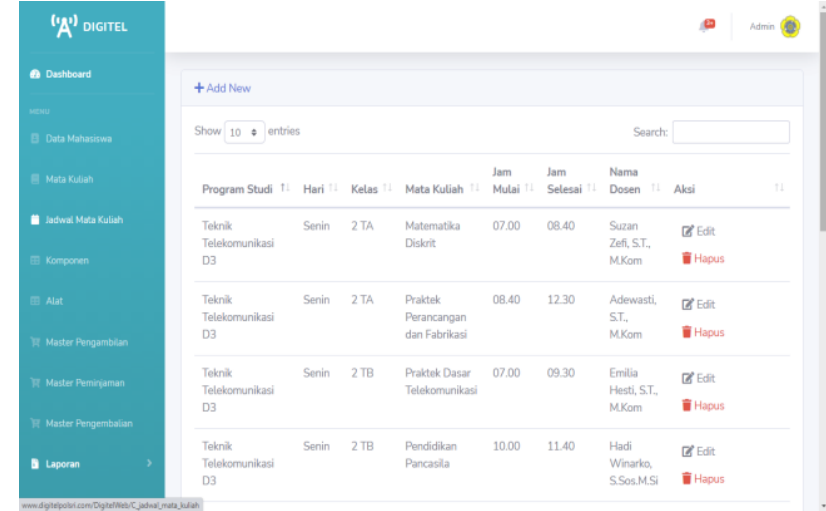

Figure 10. Course Schedule Menu

\section{Component Menu and Tools Menu}

This menu displays the tool data and provides information on the number of Components and Tools in realtime.
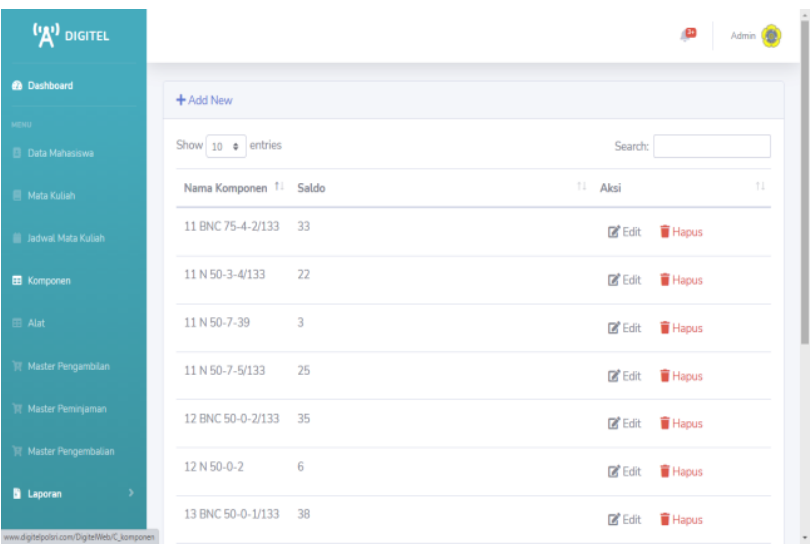

(a)
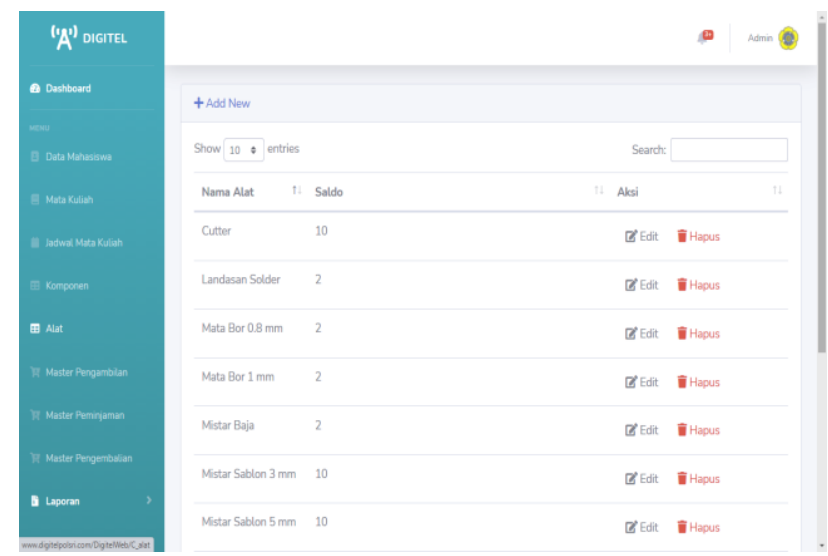

(b)

Figure 11. (a) Component Menu and (b)Tool Menu

\section{Pick up Master Menu}

Pick up Master is a menu that facilitates laboratory/workshops technicians and students in the process of providing practicum components. Simply by selecting the job name and student data, the component needs data will be displayed immediately for the loan process. Furthermore, the balance in the component menu will be automatically reduced.

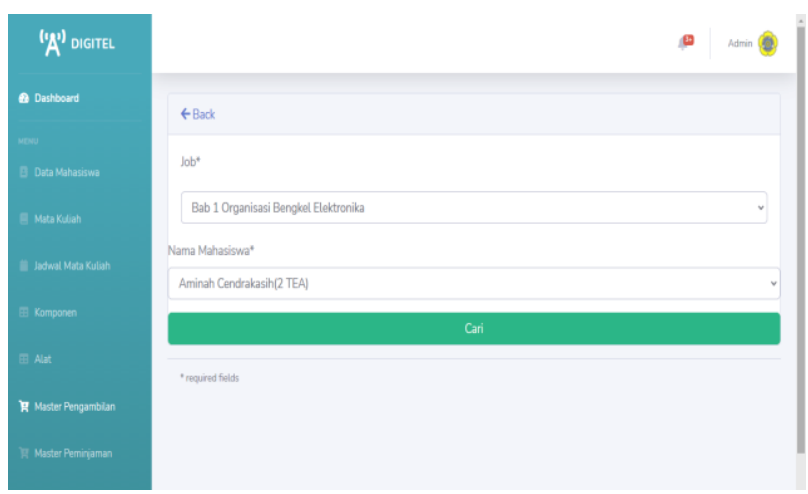

Figure 12. Pick up Master Menu

\section{Loan and Return Master Menu}

Loan and Return Master are menus that facilitate laboratory/workshops technicians and students in the process of borrowing tools/practicum instruments. Simply by selecting the job name and student data, the component needs data will be displayed immediately for the loan process. Furthermore, the balance in the tool menu will be automatically reduced. After completion of the practicum, students will be asked to return the borrowed instruments. The instrument return data will be inputted on the return master and the tool balance on the tool menu will return the initial order.

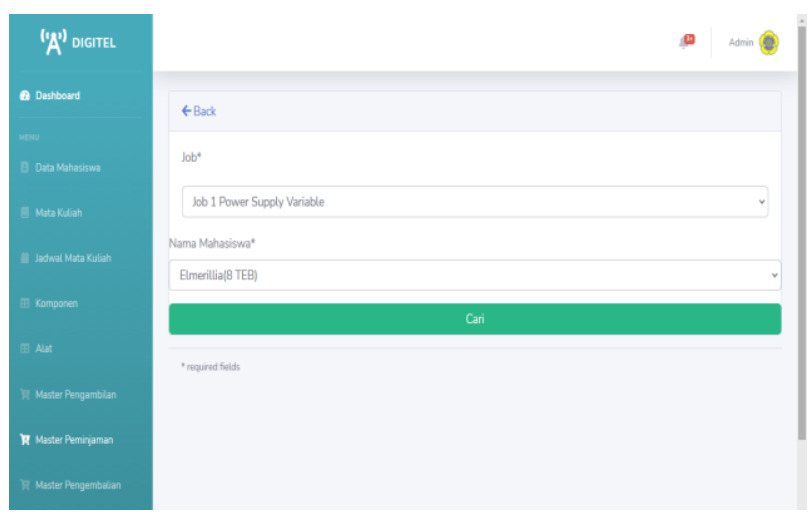

(a)

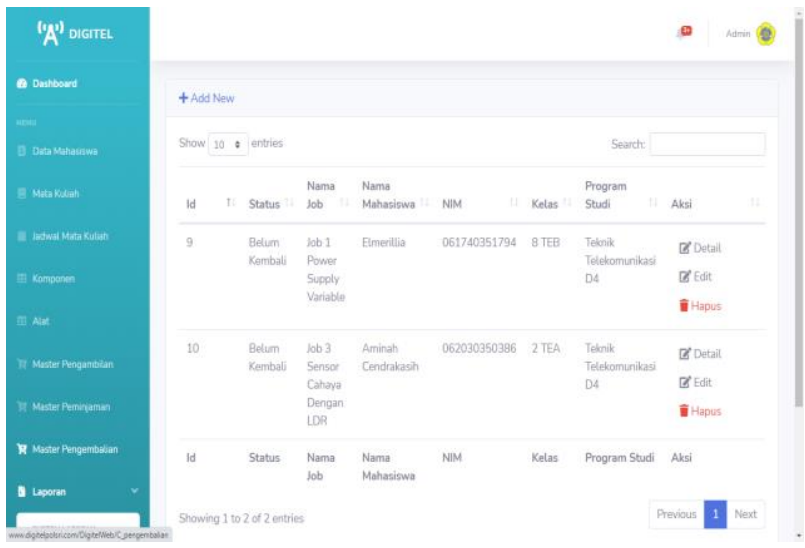

(b)

Figure 13. (a) Loan Master Menu (b) Return Master Menu 


\section{Tools Report Menu and Component Reports}

In both of these menus, the borrowed tool data and picked up components will be displayed in a PDF file. With this menu is expected no more buildup of hard file reports and all reports can be stored neatly so as to facilitate technicians in carrying out their duties.
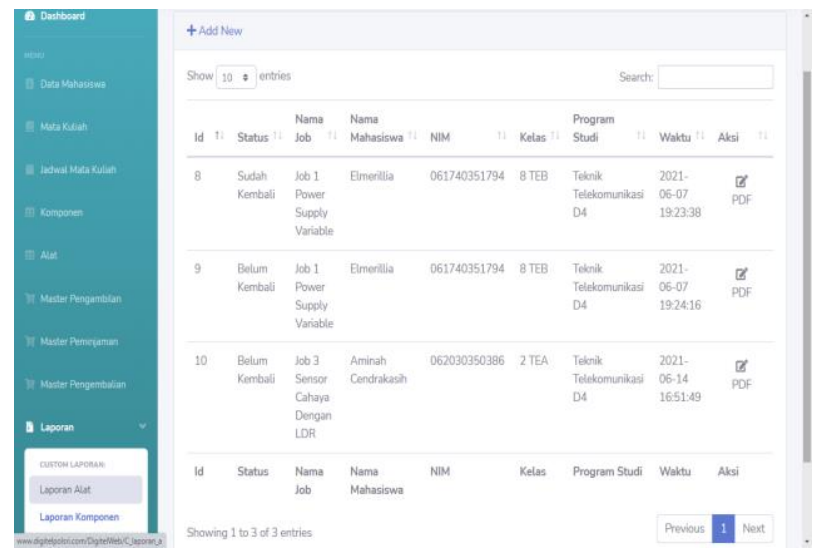

(a)

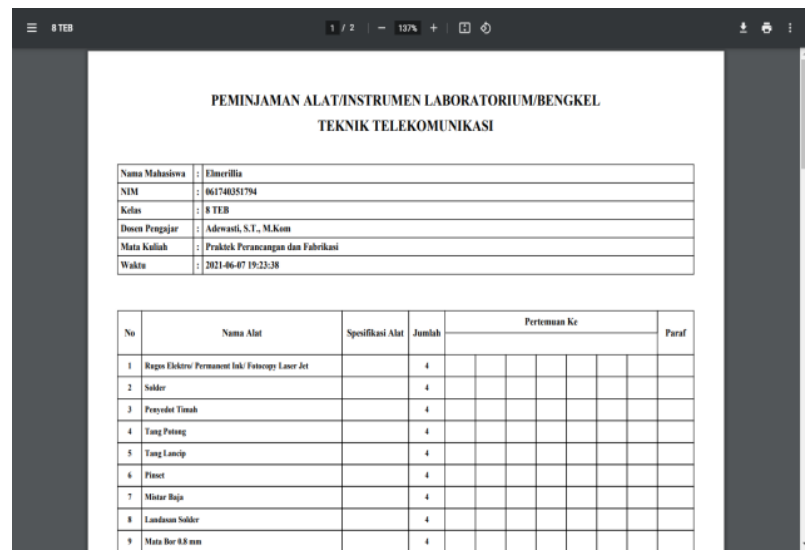

(b)

Figure 14. (a) Tool Report Menu (b) PDF data display borrowing tool

\section{Forecasting Menu}

Forecasting component requirements for the next academic year is displayed on the forecasting menu. The forecasting menu is expected to assist laboratory/workshop technicians and the inventory section in preparing the needs for practicum components. The forecasting menu is the result of calculations using the weighted moving average (WMA) method with input data on component requirements for each job and the number of students in the last 7 years.

Table 1. WMA Results Number of New Students of Applied Undergraduate of Telecommunication Engineering Study Program

\begin{tabular}{ccccc}
\hline Period & Year & $\begin{array}{c}\text { Number of } \\
\text { Students }\end{array}$ & WMA & $\begin{array}{c}\text { Error } \\
\left(\mathbf{E}_{\boldsymbol{t}}\right)\end{array}$ \\
\hline 1 & 2015 & 37 & & \\
\hline 2 & 2016 & 42 & & \\
\hline
\end{tabular}

\begin{tabular}{cccccc}
\hline 3 & 2017 & 42 & & & \\
\hline 4 & 2018 & 38 & & & \\
\hline 5 & 2019 & 37 & 39,9 & 2,9 & 1,2 \\
\hline 6 & 2020 & 43 & 38,8 & $-4,2$ & 2,52 \\
\hline 7 & 2021 & 45 & 40,1 & $-4,9$ & 3,43 \\
\hline 8 & 2022 & $\ldots \ldots$. & $\mathbf{4 2 , 1}$ & & \\
\hline
\end{tabular}

Weighted Moving Average $=$

$$
F_{t}=\frac{(45.4)+(43.3)+(37.2)+(38.1)}{10}=42,1
$$

The results of forecasting the number of new students of the Applied Undergraduate of Telecommunication Engineering Study Program in 2022 are 42,1. The WMA results will then be multiplied by the number of component requirements in one semester. So that the forecasting needs for the number of components is obtained in the following year.
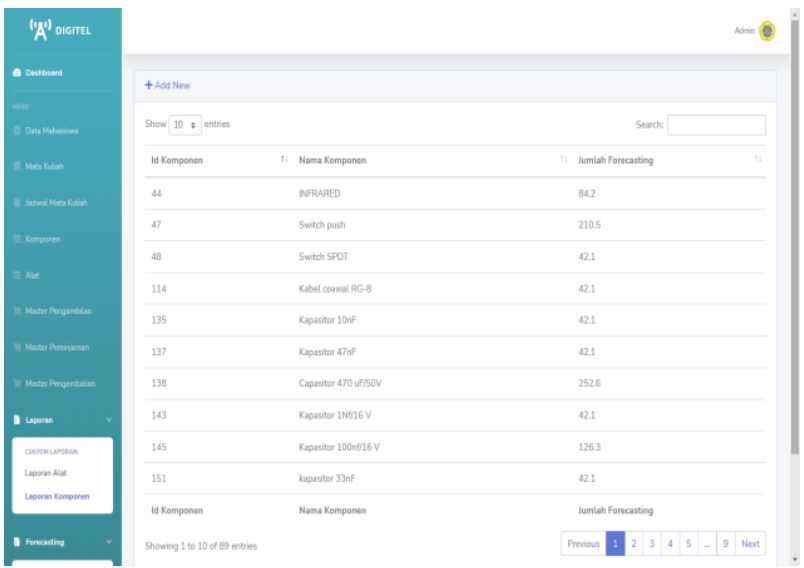

Figure 15. Forecasting Menu

\section{Program Trial}

The testing process was performed to see if the system created was valid or accepted. Testing was done with Black Box testing. From the results of the tests conducted obtained results that the application created already had a system that ran according to the procedure. The app could also display real-time data. Usability evaluation has been carried out with laboratory technicians and the application function is in accordance with the expected needs. All available menus could be used. The following are test results using black box testing:

Table 2. List of Black Box Test Results

\begin{tabular}{llc}
\multicolumn{1}{c}{ Input } & \multicolumn{1}{c}{ Observation } & Conclusion \\
\hline $\begin{array}{l}\text { Username and } \\
\text { password }\end{array}$ & $\begin{array}{l}\text { Login to the web via } \\
\text { the login form }\end{array}$ & Valid \\
\hline Logout button & Log out from web & Valid \\
\hline $\begin{array}{l}\text { Dashboard button. } \\
\text { Quick access }\end{array}$ & $\begin{array}{l}\text { Display the dashboard } \\
\text { menu. Open menu: }\end{array}$ & Valid \\
\hline
\end{tabular}




\begin{tabular}{|c|c|c|}
\hline $\begin{array}{l}\text { button on } \\
\text { dashboard : } \\
\text { - Pick up master, } \\
\text { - Loan master, } \\
\text { - Return master }\end{array}$ & $\begin{array}{l}\text { - pick up master, } \\
\text { - loan master, } \\
\text { - return master }\end{array}$ & \\
\hline $\begin{array}{l}\text { Student data } \\
\text { Menu button }\end{array}$ & View student data & Valid \\
\hline $\begin{array}{l}\text { Course Menu } \\
\text { button }\end{array}$ & View course data & Valid \\
\hline $\begin{array}{l}\text { Job button on } \\
\text { course Menu }\end{array}$ & View course job data & Valid \\
\hline $\begin{array}{l}\text { Button of } \\
\text { component detail } \\
\text { or tool details on } \\
\text { the job Menu, }\end{array}$ & $\begin{array}{l}\text { View component } \\
\text { details or tool details } \\
\text { data on the job menu: }\end{array}$ & Valid \\
\hline $\begin{array}{l}\text { Course schedule } \\
\text { Menu button, }\end{array}$ & $\begin{array}{l}\text { View course schedule } \\
\text { data }\end{array}$ & Valid \\
\hline $\begin{array}{l}\text { Component Menu } \\
\text { button, }\end{array}$ & View components data & Valid \\
\hline Tool Menu button, & View tools data, & Valid \\
\hline $\begin{array}{l}\text { Pick up master } \\
\text { Menu button, } \\
\text { search button }\end{array}$ & $\begin{array}{l}\text { Displays form of job } \\
\text { options and student } \\
\text { names }\end{array}$ & Valid \\
\hline $\begin{array}{l}\text { Loan master } \\
\text { Menu button, }\end{array}$ & $\begin{array}{l}\text { Displays form of job } \\
\text { options and student } \\
\text { names. }\end{array}$ & Valid \\
\hline $\begin{array}{l}\text { Action button in } \\
\text { pick up and loan } \\
\text { master Menu: } \\
\text { - Form of job and } \\
\text { student name, } \\
\text { - Search button }\end{array}$ & $\begin{array}{l}\text { - Displays job options } \\
\text { and student names. } \\
\text { - Displays data on the } \\
\text { need for practicum } \\
\text { components or the } \\
\text { needs for practicum } \\
\text { tools }\end{array}$ & Valid \\
\hline $\begin{array}{l}\text { Fitur button in } \\
\text { detail of pick up } \\
\text { and loan master } \\
\text { Menu: } \\
\text { - Modify button } \\
\text { - Give button on } \\
\text { tool needs view } \\
\text { in loan master }\end{array}$ & $\begin{array}{l}\text { - Modify component } \\
\text { or tool requirement } \\
\text { data. } \\
\text { - Running the system } \\
\text { give to the } \\
\text { component } \\
\text { requirements view } \\
\text { in the pick up } \\
\text { master and the } \\
\text { number of } \\
\text { components in the } \\
\text { component menu } \\
\text { will decrease, or } \\
\text { tool requirements } \\
\text { view in the loan } \\
\text { master and the } \\
\text { number of tool in } \\
\text { the tool menu will } \\
\text { decrease }\end{array}$ & Valid \\
\hline $\begin{array}{l}\text { Return master } \\
\text { Menu button, }\end{array}$ & $\begin{array}{l}\text { View loan data from } \\
\text { the loan master }\end{array}$ & Valid \\
\hline $\begin{array}{l}\text { - Detail button on } \\
\text { return master } \\
\text { Menu, } \\
\text { - Already back } \\
\text { button from the } \\
\text { return details }\end{array}$ & $\begin{array}{l}\text { - Displays data on } \\
\text { borrowed tools } \\
\text { according to the } \\
\text { process in the loan } \\
\text { master, } \\
\text { - Running the system } \\
\text { has been restored to }\end{array}$ & Valid \\
\hline
\end{tabular}

\begin{tabular}{|c|c|c|}
\hline & $\begin{array}{l}\text { change the loan } \\
\text { status and change } \\
\text { the number of tools } \\
\text { in the tool menu }\end{array}$ & \\
\hline Tool report button & $\begin{array}{l}\text { Displays a list of loans } \\
\text { that have been made } \\
\text { according to the data } \\
\text { from the loan master }\end{array}$ & Valid \\
\hline $\begin{array}{l}\text { Component report } \\
\text { button }\end{array}$ & $\begin{array}{l}\text { Displays a list of pick } \\
\text { up that have been } \\
\text { carried out according to } \\
\text { data from the pick up } \\
\text { master }\end{array}$ & Valid \\
\hline \multirow{2}{*}{$\begin{array}{l}\text { - Pdf button in } \\
\text { tool or } \\
\text { component } \\
\text { report, } \\
\text { - Button in pdf } \\
\text { report: Save } \\
\text { and print }\end{array}$} & $\begin{array}{l}\text { - Displaying a pdf file } \\
\text { of borrowed tool } \\
\text { data or displaying a } \\
\text { pdf file of pick up } \\
\text { component data }\end{array}$ & \multirow[t]{2}{*}{ Valid } \\
\hline & $\begin{array}{l}\text { - Save pdf files to } \\
\text { local pc and run the } \\
\text { print process }\end{array}$ & \\
\hline $\begin{array}{l}\text { Forecasting menu } \\
\text { button }\end{array}$ & $\begin{array}{l}\text { Shows component } \\
\text { requirement } \\
\text { forecasting }\end{array}$ & Valid \\
\hline $\begin{array}{l}\text { Action feature } \\
\text { button in web } \\
\text { menu: } \\
\text { - edit, } \\
\text { - delete, or } \\
\text { - add new }\end{array}$ & $\begin{array}{l}\text { unlock action features } \\
\text { to: } \\
\text { - modify data, } \\
\text { - clear data, } \\
\text { - add new data }\end{array}$ & Valid \\
\hline
\end{tabular}

\section{CONCLUSION}

Through the application of the prototype method, every application design process was done, taking into account the needs of the user. A trial of use has been carried out with laboratory technicians, the application forecasting components and practical tools laboratory in Telecommunication Engineering at Sriwijaya State Polytechnic web-based in general has met the needs.

The design results have provided the features of the Pick up Master Menu, Loan and Return Master Menu. Laboratory technicians can also use the report menu to display an inventory responsibility report for components and practicum tools. All menus in the application have been tested using black box testing and are acceptable.

Thus, the existence of this application can help the process of retrieving components and borrowing tools/instruments practicum laboratory in Telecommunication Engineering at State Polytechnic of Sriwijaya more effectively and efficiently and provide excellence in the process of data storage. Forecasting generated to determine component requirements in 2022 can be stated quite accurately based on the MSE value and the amount of data used. This web also provides convenience for laboratory technicians and inventory employees in preparing component needs through existing forecasting data. It is hoped that this application can be implemented in real terms so that it can help laboratory technicians and students. This application is also expected to be an example for applied in other study 
program laboratories. Furthermore, it is necessary to improve the inventory data system of entry, addition, and expenditure of components and tools in the laboratory.

\section{ACKNOWLEDGEMENT}

The author thanks to those who helped complete this final task. To Lecturers, Laboratory/Workshops Technicians, fellow students, and Administrators of the Telecommunication Engineering Study Program of State Polytechnic of Sriwijaya.

\section{REFERENCES}

[1] C. A. Cholik, "Pemanfaatan Teknologi Informasi Dan Komunikasi Untuk Meningkatkan Pendidikan Di Indonesia," Syntax Lit. J. Ilm. Indones., vol. 4, no. 6, pp. 9-15, 2017.

[2] E. Yanuarti, "Desain Aplikasi Pengelolaan Laboratorium Komputer," J. Sisfokom (Sistem Inf. dan Komputer), vol. 6, no. 1, p. 60, 2017, doi: 10.32736/sisfokom.v6il.181

[3] T. F. Tambuwun, R. Sengkey, Y. D. Y. Rindengan, T. Sam, and R. Manado, "Perancangan Aplikasi Web Berbasis Usability," J. Tek. Inform., vol. 12, no. 1, 2017, doi: 10.35793/jti.12.1.2017.17856.

[4] S. P. Indriyani and D. Kurniadi, "Rancang Bangun Sistem Informasi Pelayanan Unit Sistem Informasi," J. Algoritm., vol. 6, no. October, pp. 68-75, 2017, [Online]. Available: https://www.researchgate.net/publication/320191925_Ra ncang_Bangun_Sistem_Informasi_Pelayanan_Unit_Sist em_Informasi_Sekolah_Tinggi_Teknologi_Garut_Berba sis_Web_dan_AndroidM.M.A. Abdelaziz, M.F. Shaaban, H.E. Farag, and E.F. El-Saadany, "A Multistage Centralized Control Scheme for Islanded Microgrids With PEVs," IEEE Transaction on Sustainable Energy, vol. 5, no. 3, pp. 927-937, July 2014.

[5] A. Ismawari, B. Sitepu ${ }^{1}$, D. Yani, and H. Tanjung ${ }^{2}$, "Rancang Bangun Aplikasi Pemesanan dan Penjualan Berbasis Web dan Android pada Toko YT. Wall Interior," J. FTIK, vol. 1, no. 1, pp. 816-828, 2020, [Online]. Available: http://e-journal.potensiutama.ac.id/ojs/index.php/FTIK/article/view/927.

[6] D. A. Punkastyo, "Perancangan Aplikasi Tutorial Jurus Dasar Beladiri Cimande Menggunakan Metode Prototype," J. Inform. Univ. Pamulang, vol. 3, no. 2, p. 87, 2018, doi: 10.32493/informatika.v3i2.1433.

[7] H. L. H. S. W. Aristo Putramasi Hintarsyah, Jessica Christy, "Forecasting Sebagai Decision Support Systems Aplikasi dan Penerapannya Untuk Mendukung Proses Pengambilan Keputusan.," J. Sist. Komput., vol. 8, no. 1, pp. 19-27, 2018.

[8] A. Nasution, "Metode Weighted Moving Average Dalam M-Forecasting Pendahuluan Teknologi mobile sekarang ini berkembang pesat, seperti terlihat dari lembaga riset digital marketing, emarketer yang memperkirakan pada 2018 jumlah pengguna aktif smartphone di Indonesia le," vol. V, no. 2, pp. 119-124, 2019.

[9] S. A. Wulandari, "Sistem Informasi Penjualan Produk Berbasis Web Pada Chanel Distro Pringsewu," J. TAM (Technology Accept. Model., vol. 4, no. 0, pp. 41-47, 2017, [Online]. Available: http://ojs.stmikpringsewu.ac.id /index.php/ JurnalTam/ article/view/36/36.
[10] J. Agape Sianturi, I. N. Piarsa, and I. K. Adi Purnawan, "Aplikasi Pencarian dan Penyewaan Rumah Kost Berbasis Web dan Android," J. Ilm. Merpati (Menara Penelit. Akad. Teknol. Informasi), vol. 6, no. 3, p. 192, 2018, doi: 10.24843/jim.2018.v06.i03.p06.

[11] E. R. Subhiyakto and Y. P. Astuti, "Aplikasi Pembelajaran Class Diagram Berbasis Web Untuk Pendidikan Rekayasa Perangkat Lunak," Simetris J. Tek. Mesin, Elektro dan Ilmu Komput., vol. 11, no. 1, pp. 143150, 2020, doi: 10.24176/simet.v11i1.3787.

[12] E. Kurniawan and A. K. Syahputra, "Perancangan Aplikasi Pemesanan Dan Pembayaran Berbasis Desktop Pada Percetakan UD. AZKA GEMILANG Menggunakan Metode Prototype," Semin. Nas. Raya, vol. 9986, no. September, pp. 105-110, 2018.

[13] A. Syarifudin, "Perancangan Sistem Informasi Pengajuan dan Pelaporan Pembayaran Tunjangan Kinerja Kementerian Keuangan Menggunakan Metode Prototype,' J. Sisfokom (Sistem Inf. dan Komputer), vol. 8, no. 2, p. 149, 2019, doi: 10.32736/sisfokom.v8i2.641.

[14] B. A. Priyaungga, D. B. Aji, M. Syahroni, N. T. S. Aji, and A. Saifudin, "Pengujian Black Box pada Aplikasi Perpustakaan Menggunakan Teknik Equivalence Partitions," J. Teknol. Sist. Inf. dan Apl., vol. 3, no. 3, p. 150, 2020, doi: 10.32493/jtsi.v3i3.5343.

[15] Ramadania, "Peramalan Harga Beras Bulanan di Tingkat Penggilingan dengan Metode Weighted Moving Average,' Bimaster, vol. 7, no. 4, pp. 329-334, 2018, [Online]. Available: http://jurnal.untan.ac.id/index.php/jbmstr/article/view/28 402/75676578415. 